DOI: https://doi.org/10.24127/ajpm.v9i1.2609

\title{
PENGARUH SPSS TERHADAP HASIL BELAJAR PADA MATERI STATISTIKA DESKRIPTIF
}

\author{
Nurhayati $^{1}$, Novianti ${ }^{2}$ \\ ${ }^{1,2}$ Pendidikan Matematika, Universitas Almuslim Bireuen, Aceh, Indonesia \\ E-mail: $\quad \frac{\text { nurhayati09.nur@gmail.com }}{\text { novianti.idr@gmail.com }}{ }^{2)}$
}

Received 13 January 2020; Received in revised form 29 January 2020; Accepted 28 March 2020

\begin{abstract}
Abstrak
Tujuan dari penelitian ini adalah untuk mengetahui apakah terdapat perbedaan hasil belajar mahasiswa PGSD yang diajarkan dengan menggunakan SPSS dengan yang diajarkan dan menggunakan pembelajaran konvensional pada materi statistika deskriptif di Universitas Almuslim. Penelitian dilakukan dengan menggunakan pendekatan kuantitatif dan jenis penelitian true eksperimental. Adapun yang menjadi populasi dalam penelitian ini adalah seluruh mahasiswa PGSD Universitas Almuslim semester V yang terdiri dari 4 kelas dan berjumlah 240 mahasiswa sedangkan yang menjadi sampel yaitu kelas V/A sebagai kelas eksperimen dan kelas V/C sebagai kelas kontrol yang masing-masing berjumlah 30 orang. Instrumen pengumpul data dalam penelitian ini berupa tes yang diberikan melalui post-test. Berdasarkan hasil analisis data menggunakan uji $\mathrm{t}$ independent sample test diperoleh nilai sig. (2 Tailed) yaitu 0.023. Hal ini menunjukkan bahwa nilai sig. (2 Tailed) $<5 \%$ maka $H_{0}$ ditolak, artinya hasil belajar mahasiswa yang diajarkan dengan menggunakan SPSS lebih baik dari pada yang diajarkan dengan menggunakan pembelajaran konvensional.
\end{abstract}

Kata kunci: hasil belajar; SPSS; statistika.

\begin{abstract}
The purpose of this study is to determine whether there are differences in the learning outcomes of PGSD students who are taught using SPSS with those taught and use conventional learning on descriptive statistics material at Almuslim University. The study was conducted using a quantitative approach and a type of true experimental research. As for the population in this study were all semester 5 PGSD Almuslim University students consisting of 4 classes and totaling 240 students while the sample was class V/A as an experimental class and class V/C as a control class, each amounting to 30 person. Data collection instruments in this study in the form of tests provided through post-test. Based on the results of data analysis used the Independent Sample Test t test obtained sig. (2 Tailed) which is 0.023. This shows that the value of sig. $\left(2\right.$ Tailed) $<5 \%$, then $\mathrm{H}_{0}$ is rejected, meaning that student learning outcomes taught using SPSS are better than those taught using conventional learning.
\end{abstract}

Keywords: learning outcomes; SPSS; statistics

\section{PENDAHULUAN}

Pendidikan merupakan suatu acuan yang menjadi tolak ukur bagi perkembangan dan kemajuan ilmu pengetahuan dan teknologi untuk menghadapi persaingan global. Salah satu ilmu pengetahuan yang harus dikuasai adalah matematika. Matematika merupakan suatu ilmu pengetahuan yang mampu menumbuhkan kemampuan berpikir logis, kritis, sistematis, dan kreatif. Menurut Siagian (2016) matematika merupakan salah satu cabang ilmu pengetahuan yang mempunyai peranan penting dalam perkembangan ilmu pengetahuan dan teknologi, baik sebagai alat bantu dalam penerapanpenerapan bidang ilmu lain maupun dalam pengembangan matematika itu sendiri. Pembelajaran matematika hendaknya disesuaikan dengan konsep 
DOI: https://doi.org/10.24127/ajpm.v9i1.2609

atau pokok bahasan dan perkembangan peserta didik. Menurut Nurhayati (2019) dalam proses belajar mengajar matematika, pendidik harus mampu menciptakan suasana yang menyenangkan dan terus berinovasi dalam menyajikan suatu materi pembelajaran di kelas. Peserta didik dianggap sebagai subjek pembelajaran dan dituntut untuk memiliki kemandirian belajar.

Hal tersebut bertentangan dengan realita yang terjadi saat ini. Berdasarkan hasil observasi lapangan dan wawancara dengan Bapak Suherman M. Si yang merupakan dosen di salah satu universitas di Aceh, dalam proses pembelajaran pendidik menjadi pusat informasi bagi peserta didik dan kemandirian belajar peserta didik masih sangat kurang. Hal ini sejalan dengan penelitian Nurhayati (2018) dalam kegiatan belajar, peserta didik bukanlah ibarat botol kosong yang harus diisi dengan muatan-muatan informasi apa saja yang dianggap perlu oleh pendidik.

Apabila permasalahan ini terus diterapkan dalam proses pembelajaran matematika khususnya pada mata kuliah statistika, hasilnya tidak akan maksimal. Materi statistika kurang diminati dan masih dianggap sebagai sesuatu yang menakutkan oleh beberapa mahasiswa. Hal ini disebabkan statistika banyak rumus-rumus, perlu ketelatenan, kecermatan dan ketelitian dalam mempelajarinya. Akibatnya motivasi belajar mahasiswa terhadap materi ini menjadi rendah sehingga hasil belajar yang diperoleh akan menurun. Berdasarkan hasil evaluasi belajar mahasiswa PGSD pada mata kuliah statistik tahun akademik 2018/2019 di Universitas Almuslim, menunjukkan bahwa nilai mahasiswa yang memperoleh nilai A sampai B hanya mencapai $35 \%$, sedangkan sisanya $65 \%$ mahasiswa memperoleh nilai dibawah
B. Hal ini menunjukkan bahwa rata-rata mahasiswa masih kurang mampu dalam mengerjakan evaluasi yang diberikan.

Berdasarkan hal tersebut tampaknya perlu adanya perubahan paradigma dalam proses pembelajaran pada mata kuliah statistika. Salah satu teknologi yang bisa dimanfaatkan sebagai media pembelajaran adalah SPSS (Statistical Program for Social Science). SPSS merupakan salah satu aplikasi yang sering digunakan dalam mengolah data. Menurut Jayadi \& Anwar (2017) SPSS juga dapat diartikan sebagai sebuah program aplikasi yang memiliki kemampuan analisis statistik yang cukup tinggi serta sistem manajemen data pada lingkungan grafiks dengan menggunakan menumenu deskriptif dan kota-kota dialog yang sederhana sehingga mudah untuk dipahami mengenai cara pengoperasiannya.

Beberapa penelitian yang telah dilakukan dengan menggunakan SPSS yaitu penelitian oleh Trimurtini, Wahyuningsih, Nugraheni, \& Susilaningsih (2016) menunjukkan bahwa hasil belajar mahasiswa pada perkuliahan statistika pendidikan dengan metode Mind Mapping berbantuan SPSS lebih baik jika dibandingkan dengan model kooperatif di jurusan S1 PGSD FIP UNNES. Sofia \& Ervan (2016) menunjukkan bahwa hasil perhitungan uji hipotesis tidak memiliki pengaruh yang nyata terhadap prestasi belajar statistik mahasiswa IKIP PGRI Madiun. Nurizzati (2016) menyatakan bahwa Pembelajaran statistik dasar menggunakan metode praktikum berbasis pendidikan karakter islami efektif digunakan untuk meningkatkan kemampuan mahasiswa.

Selanjutnya penelitian oleh Riyanto \& Nugrahanti (2018) hasil Penelitian Tindakan Kelas memberikan informasi bahwa kemampuan mahasiswa dalam menjalankan aplikasi SPSS dan cara membaca makna angka 
statistik dari output SPSS dinilai cukup baik dan mengalami peningkatan dari siklus satu. Adapun penelitian oleh Ramadhani dan Sribina (2019) menunjukkan bahwa pemanfaatan media pembelajaran SPSS dalam pembelajaran matematika untuk meningkatkan kemampuan statistik diperoleh rata-rata persentase angket berada pada tingkat persentase $69.5 \%$ dan masuk dalam katagori baik).

Dari beberapa penelitian tersebut belum ada yang meneliti tentang pengaruh SPSS terhadap hasil belajar mahasiswa pada materi statistika deskriptif. Penggunaan SPSS dapat melatih peserta didik secara mandiri untuk terlibat secara aktif dalam proses pembelajaran sehingga terampil dalam menyelesaikan masalah, terampil dalam membaca hasil dari pengolahan SPSS dan dapat meningkatkan hasil belajar. Hasil belajar dapat merefleksikan keluasan, kedalaman, kompleksitas dan digambarkan secara jelas serta dapat diukur dengan teknik-teknik penilaian tertentu. Menurut Fatyana \& Jasmaniah (2019) mengemukakan bahwa hasil belajar adalah suatu penilaian akhir dari proses dan pengenalan yang telah dilakukan berulang-ulang, serta akan tersimpan dalam jangka waktu lama atau bahkan tidak akan hilang selamalamanya. Hal ini dikarenakan hasil belajar turut serta dalam membentuk pribadi individu yang selalu ingin mencapai hasil yang lebih baik lagi sehingga akan merubah cara berpikir serta menghasilkan prilaku kerja yang lebih baik. Jadi, dapat disimpulkan bahwa hasil belajar adalah nilai akhir yang diperoleh oleh peserta didik setelah menghadapi proses pembelajaran.

Berdasarkan permasalahan di atas, tujuan penelitian ini adalah untuk mengetahui apakah terdapat perbedaan hasil belajar mahasiswa PGSD yang diajarkan dengan menggunakan SPSS dan yang diajarkan dengan menggunakan pembelajaran konvensional pada materi statistika deskriptif di Universitas Almuslim.

\section{METODE PENELITIAN}

Penelitian ini termasuk jenis penelitian true experimental dimana adanya dua perlakuan yang berbeda antara kelas eksperimen dengan kelas kontrol. Adapun pendekatan yang digunakan dalam penelitian ini adalah pendekatan kuantitatif dengan menggunakan uji-t untuk mengetahui apakah terdapat perbedaan hasil belajar mahasiswa PGSD yang diajarkan dengan menggunakan SPSS dan pembelajaran konvensional pada materi statistika deskriptif. Desain penelitian yang digunakan adalah Post Test - Only Control Design (Setyanto: 2013). Adapun bentuk rancangan penelitian ini akan ditunjukkan pada Tabel 1 .

Tabel. 1 Rancangan penelitian.

\begin{tabular}{ccc}
\hline Sampel & Perlakuan & $\begin{array}{c}\text { Post } \\
\text { Test }\end{array}$ \\
\hline Kelas Eksperimen & $\mathrm{X}$ & $\mathrm{O}_{1}$ \\
Kelas Kontrol & - & $\mathrm{O}_{2}$ \\
\hline
\end{tabular}

Populasi dalam penelitian ini adalah seluruh mahasiswa PGSD Universitas Almuslim semester $\mathrm{V}$ yang terdiri dari 4 Kelas. Dari 4 kelas yang tersedia dipilih 2 kelas yaitu kelas V/A dan V/C yang masing-masing jumlah siswanya 30 orang sebagai sampel yang diambil secara cluster random sampling. Kelas V/A sebagai kelas eksperimen dan kelas V/C sebagai kelas kontrol. Instrumen yang digunakan adalah tes. Tes ini akan diberikan kepada 60 mahasiswa yang berisi soalsoal tentang statistika deskriptif. Data dalam penelitian ini diperoleh dari hasil mengajar materi statistika deskriptif 
dengan menggunakan SPSS untuk kelas eksperimen dan dengan menggunakan pembelajaran konvernsional untuk kelas kontrol. Setelah proses pembelajaran berakhir, mahasiswa diberikan tes sebagai hasil dari proses belajar mengajar dan sekaligus dijadikan sebagai data dalam penelitian ini. Tes tersebut akan diberikan untuk kelas eksperimen dan kelas kontrol dengan waktu dan soal yang sama. Kemudian data tersebut dianalisis menggunakan uji-t dengan bantuan SPSS.

\section{HASIL DAN PEMBAHASAN}

Kelas eksperimen memiliki nilai rata-rata yang lebih tinggi dibandingkan dengan kelas kontrol. Hal ini menunjukkan bahwa terjadi peningkatan nilai rata-rata kelas eksperimen dimana proses pembelajaran dengan SPSS dapat meningkatkan hasil belajar. Sebaliknya, untuk nilai variansi dan simpangan baku pada kelas kontrol lebih besar dibandingkan dengan kelas eksperimen. Hal ini menunjukkan bahwa data dari kelas kontrol memiliki nilai hasil belajar yang bervariasi. Adapun rekapitulasi hasil tes dari kelas eksperimen dan kelas kontrol dapat dilihat pada Tabel 2.

Tabel 2. Rekapitulasi hasil tes.

\begin{tabular}{ccc}
\hline Statistik & $\begin{array}{c}\text { Kelas } \\
\text { Eksperimen }\end{array}$ & $\begin{array}{c}\text { Kelas } \\
\text { Kontrol }\end{array}$ \\
\hline $\boldsymbol{n}$ & 30 & 30 \\
$\overline{\boldsymbol{x}}$ & 72.83 & 58.50 \\
$\boldsymbol{s}^{2}$ & 260.23 & 293,79 \\
$\mathbf{S}$ & 16.13 & 17.14 \\
\hline
\end{tabular}

Dalam penelitian ini terlebih dahulu akan dilakukan pengujian normalitas dan homogenitas terhadap hasil tes dari kelas eksperimen dan kelas kontrol. Pengujian normalitas dilakukan untuk melihat apakah data yang diperoleh sudah normal atau belum. Adapun hasil rekapitulasi dari pengujian normalitas dapat dilihat pada Tabel 3.

Tabel 3. Hasil pengujian normalitas.

\begin{tabular}{ccc}
\hline \multirow{2}{*}{ Data } & \multicolumn{2}{c}{ Kolmogorov Smirnov } \\
\cline { 2 - 3 } & Lavene Statistic & Sig. \\
\hline Kelas Eksperimen & 0.359 & 0.176 \\
Kelas Kontrol & 0.216 & 0.287 \\
Kesimpulan & \multicolumn{2}{c}{ Normal } \\
\hline
\end{tabular}

Berdasarkan Tabel 3 dapat diketahui bahwa nilai sig. dari kelas eksperimen sebesar 0.176 dan kelas kontrol sebesar 0.287 dimana keduanya memiliki nilai yang lebih besar dari taraf kepercayaan 5\% sehingga dapat dikatakan bahwa bahwa kedua data tersebut berdistribusi normal. Selanjutnya, akan dilakukan pengujian homogenitas, pengujian ini dilakukan untuk menguji kesamaan dua variabel. Adapun hasil rekapitulasi dari pengujian homogenitas dapat dilihat pada Tabel 4.

Tabel 4. Hasil pengujian homogenitas.

\begin{tabular}{ccc}
\hline Statistik & $\begin{array}{c}\text { Kelas } \\
\text { Ekasperimen }\end{array}$ & $\begin{array}{c}\text { Kelas } \\
\text { Kontrol }\end{array}$ \\
\hline Lavene Statistic & 1.322 & 0.240 \\
Sig. & 0.247 & 0.196 \\
Kesimpulan & \multicolumn{2}{c}{ Homogen } \\
\hline
\end{tabular}

Berdasarkan Tabel 4 dapat diketahui bahwa nilai sig. dari kelas eksperimen sebesar 0.247 dan kelas kontrol sebesar 0.196 dimana keduanya memiliki nilai yang lebih besar dari taraf kepercayaan 5\% sehingga dapat dikatakan bahwa hasil belajar dari kedua kelas tersebut homogen. Selanjutnya, untuk mengetahui apakah terdapat perbedaan hasil belajar yang diajarkan dengan menggunakan SPSS dan pembelajaran konvensional, maka akan dianalisis menggunakan uji-t. 
DOI: https://doi.org/10.24127/ajpm.v9i1.2609

Adapun pengujian keputusan hipotesis adalah sebagai berikut:

$H_{0}: \mu_{1}=\mu_{2}$

Hasil belajar mahasiswa yang diajarkan dengan menggunakan SPSS sama dengan hasil belajar pembelajaran konvensional.

\section{$H_{a}: \mu_{1}>\mu_{2}$}

Hasil belajar mahasiswa yang diajarkan dengan menggunakan SPSS lebih baik dari pada hasil belajar pembelajaran konvensional.

Uji hipotesis dalam penelitian ini menggunakan "Independent Sample Test" dengan taraf kepercayaan 5\%, Adapun kriteria pengujiannya adalah sebagai beriku: "kriteria pengujian yang berlaku adalah jika $\mathrm{P}_{\text {value }}>0.05$ maka $H_{0}$ diterima dan jika $\mathrm{P}_{\text {value }}<0.05$ maka $H_{0}$ ditolak. Adapun hasil rekapitulasi dari uji hipotesis dapat dilihat pada Tabel 5.

Tabel 5. Hasil uji hipotesis.

\begin{tabular}{ccc}
\hline T & df & Sig. (2 Tailed) \\
\hline 3.31 & 58 & 0.023 \\
\hline
\end{tabular}

Berdasarkan Tabel 4 maka hasil analisis data menggunakan uji $\mathrm{t}$ independent sample test diperoleh nilai nilai sig. (2 Tailed) yaitu 0.023 . Hal ini menunjukkan bahwa nilai sig. (2 Tailed) $<$ taraf kepercayaan 5\% maka $H_{0}$ ditolak, artinya hasil belajar mahasiswa yang diajarkan dengan menggunakan SPSS lebih baik dari pada yang diajarkan dengan menggunakan pembelajaran konvensional.

Dari hasil penelitian menunjukkan adanya pengaruh hasil belajar mahasiswa dengan menggunakan SPSS. Hasil belajar mahasiswa dengan menggunakan SPSS lebih baik dari pada hasil belajar menggunakan pembelajaran konvensional. Hal ini dikarenakan pada pembelajaran dengan menggunakan SPSS terlibat secara aktif dalam proses pembelajaran sehingga terampil dalam menyelesaikan masalah, terampil dalam membaca hasil dari pengolahan SPSS dan dapat meningkatkan hasil belajar. Akibatnya, bukan hanya untuk meningkatkan hasil belajar tetapi juga dapat menambah wawasan dan semakin mahir dalam memanfaatkan SPSS. Temuan ini senada dengan beberapa penelitian lain tentang penggunaan SPSS (Trimurtini, Wahyuningsih, Nugraheni, \& Susilaningsih, 2016); (Nurizzati (2016); (Riyanto \& Nugrahanti (2018); Ramadhani dan Sribina 2019). Namun, bertentangan dengan penelitian yang dilakukan oleh (Sofia \& Ervan 2016).

Implikasi teoritis dari penelitian ini yaitu SPSS dapat meningkatkan hasil belajar baik dari ranah kognitif, afektif, dan psikomotorik. Penggunaan SPPS dalam mata kuliah stsatistik memberikan pengaruh terhadap hasil belajar mahasiswa. Hal ini dikarenakan dalam proses pembelajarannya dilakukan dengan mengkombinasikan teknik hitung manual dengan SPSS. Adapun implikasi terapannya adalah tindakan proses pembelajaran yang dilakukan pendidik dan peserta didik dapat memberikan gambaran mengenai kemandirian dan hasil belajar dapat ditingkatkan. Penerapan SPSS dalam belajar statistik dapat menjadikan peserta didik termotivasi dan senang untuk belajar statistik. Meningkatnya kemampuan peserta didik dalam memecahkan masalah yang berhubungan dengan statistik maka akan berdampak pada meningkatnya hasil belajarnya. Dengan adanya SPSS diharapkan mahasiswa mampu termotivasi untuk terus mempelajari statistik lebih mendalam lagi serta dapat 
memberikan manfaat kepada temanteman sehingga mampu tumbuh dan berkembang menjadi pribadi yang kritis, kreatif, mandiri serta mampu beradaptasi dengan perkembangan revolusi industri 4.0.

\section{KESIMPULAN DAN SARAN}

Berdasarkan hasil penelitian dan pembahasan maka dapat disimpulkan bahwa terdapat perbedaan hasil belajar mahasiswa PGSD yang diajarkan dengan menggunakan SPSS dan pembelajaran konvensional pada materi statistika deskriptif di Universitas Almuslim. Hasil belajar mahasiswa dengan menggunakan SPSS lebih baik dari pada hasil belajar menggunakan pembelajaran konvensional.

Adapun saran dari penelitian ini diharapkan dapat dijadikan alternatif proses pembelajaran mata kuliah statistika menggunakan aplikasi SPSS atau aplikasi lainnya dengan mengkombinasikan dengan teknik hitung manual. Selanjutnya, untuk penelitian lebih lanjut penggunaan SPSS atau aplikasi lainnya yang berhubungan dengan statistik bagi mahasiswa FKIP Universitas Almuslim perlu dikenalkan lebih luas, tidak hanya untuk proses pembelajaran saja, tetapi juga dapat dimanfaatkan dalam pengolahan data saat akan skripsi dan dalam penelitian mahasiswa.

\section{DAFTAR PUSTAKA}

Fatyana \& Jasmaniah. (2019). Upaya Meningkatkan Hasil Belajar Siswa pada Materi Penjumlahan dan Pengurangan Bilangan Bulat dengan Menggunakan Teori Bruner di Kelas V SD Negeri 4 Bireuen. Jurnal Pendidikan Almuslim 7(1), 22-31.
Jayadi, A., \& Anwar, Z. (2017). Pemanfaatan Aplikasi SPSS untuk Meningkatkan Keterampilan Mahasiswa Mengolah Data Statistika. Jurnal Visionary, 4(2), 111-113.

Nurizzati, Y. (2016). Efektifitas Pembelajaran Statistik Dasar dengan Metode Praktikum berbasis Pendidikan Karakter Islam di Jurusan Tadris Ilmu Pengetahuan Sosial IAIN Syekh Nurjati Cirebon. Jurnal Holistik, 1(1), 36-48.

Nurhayati. (2018). Pengaruh Teknik Pembelajaran Buzz(Buzz Group) Terhadap Hasil Belajar Siswa pada Materi Statistika di kelas XI SMA Negeri 3 Bireuen. LENTERA: Jurnal Ilmiah Sains, Teknologi, Ekonomi, Sosial, dan budaya, 2(1), 12-15.

Nurhayati. (2019). Pengaruh Strategi Pembelajaran Plantet Questions Terhadap Prestasi Belajar Siswa pada Materi Trigonometri di Kelas X SMAN 1 Bireuen. Jurnal Pendidikan Almuslim, 7(1), 45-49.

Ramadhani, R., \& Sribina, N. (2019). Pemanfaatan Media Pembelajaran SPSS untuk Meningkatkan kemampuan Statistik Siswa SMK. Jurnal Solma, 8(1), 159-170.

Riyanto, S., \& Nugrahanti, F. (2018). Pengembangan Pembelajaran Statistika Berbasis Praktikum Aplikasi Software SPSS dengan Bantuan Multimedia untuk mempermudah Pemahaman Mahasiswa Terhadap Ilmu Statistika. DoubleClick: Jurnal of Computer and Information Technology, 1(2), 62-67. 
DOI: https://doi.org/10.24127/ajpm.v9i1.2609

Setyanto, A. E. (2013).

Memperkenalkan Kembali Metode Eksperimen dalam Kajian Komunikasi. Jurnal Ilmu Komunikasi, 3(1), 37-48.

Siagian, M., D. (2016). Kemampuan Koneksi Matematik dalam Pembelajaran Matematika. MES: Journal of Mathematics Education and Science, 2(1), 5867.

Sofia, N. A., \& Ervan, J. W. (2016). Persepsi Mahasiswa tentang Mata kuliah Statistik serta Pengaruhnya terhadap Prestasi Belajar Statistik Mahasiswa IKIP PGRI Madiun. Jurnal LPPM, 4(1), 46-49.

Trimurtini, Wahyuningsih, Nugraheni, N., \& Susilaningsih, S. (2016). Penerapan Metode Mind Mapping Berbantuan SPSS pada Mata Kuliah Statistika Pendidikan. Jurnal Litbang Provinsi Jawa Tengah, 2(4), 205-214. 